significant difference was observed between groups (group I: 263 days; group 2: 263 days; group 3: 255 days).

As compared with the other groups, the weight at puberty of gilts in group 1 was significantly lower and so was the ovulation rate (group I: I0,4; group 2: 12,6 ; group 3: I 2.6). This lowering of the ovulation rate affected the litter size at 3 o days (group $1: 8.5$; group $2: 9.3 ;$ group 3 : 10.7), but not a.t farrowing (group 1: 8.5 ; group 2: 8.5 ; group 3 : 8.5).

\title{
Use of horse-bean in pregnant gilt diets
}

\author{
M. ÉTIENNE \\ Station de Recherches sur l'Elevage des Porcs, \\ I.N.R.A.-C.N.R.Z., 78350 Jouy-en-Josas (France)
}

In the present experiment, 54 nulliparous Large White gilts were used to study the effects of a total substitution of soya-bean meal for whole horse-bean in the gestation diet on the survival and development of the embryos. The animals were distributed into three groups. Groups I and 2 received a diet containing 8 per cent soya-bean meal and 15 per cent "Ascott" horse-bean, respectively ensuring the same protein supply (12.3 per cent crude protein). The diet of the gilts of group 3 included 25 per cent horse-bean in order to measure the eventual effects of a higher supply of this feedstuff. Between mating at puberty (255 days of age, I $7 \mathrm{~kg}$ ) and slaughter at 105 days of pregnancy, the gilts received daily $2.2 \mathrm{~kg}$ of their respective diets.

The proportion of non-fertilized gilts was the same in the three groups $(24 \%)$. No difference appeared between the fenules with respect to weight gain (55 kg), ovulation rate (13.5), mean weight of corpora lutea $(0.53 \mathrm{~g})$ and total weight of ovaries ( $13.12 \mathrm{~g})$. This was also the case for the number of normal $(9.4 \mathrm{I})$ or abnormal foetuses $(0.37)$ per litter and total embryonic mortality (29.8 per cent). However, the individual weight was lower for foetuses $(923,825$ and $854 \mathrm{~g}$, respectively in groups 1,2 and 3$)$ and placentas $(212,184$ and $194 \mathrm{~g})$ of the gilts fed with horsebean (groups 2 and 3 ). This suggests that the embryonic mortality might be increased in these animals in the case of a ligher prolificacy, since the resulting greater competition among foetuses would more affect less vigourous individuals. However that may be, the horse-bean factors responsible for reduction in the weight of foetuses have not yet been determined.

\section{Use of a potato protein concentrate in the diet of piglets weaned at 10 or at 21 days}

\author{
B. SÈVE
}

Station de Recherches sur l'Elevage des Porcs, I.N.R.A.-C.N.R.Z., 78350 Jouy-en-Josas (France)

\footnotetext{
The nutritive value of a potato protein concentrate (CPDT $=$ PPC: 83.5 per cent of $N \times 6,25$ 6.3 per cent lysine/dry matter) was estimated during two experiments each including 6 piglets weaned at io or at $2 \mathrm{I}$ days.

In the first experiment, the piglets primaily received lst age diets containing 25 per cent crude protein out of which 50 per cent was skim-milk. The other fraction ( $5^{\circ}$ per cent) was constituted of dissolved fish (CPSP $=\mathrm{DFPC}$ ) in groups I (control) and 2 ; in groups 3 and 4 , this fraction was composed of 25 per cent DFPC and 25 per cent PPC, finely ground or not, in group 5. 50 per
} 